\title{
Conclusion
}

The positive effects of this system combined with more efficient utilization of family labor and its flexibility to meet different socio-economic and productive realities, makes the silvopastoral system a feasible and sustainable alternative for the smallholders of Misiones, Argentina.

\section{Comparing energy use efficiency and green house gas emissions for livestock products}

\author{
Jonathan Vayssieres ${ }^{\dagger}$, Alexandre Thevenot, Mathieu Vigne, Emmanuel Tillard and Philippe Lecomte
}

CIRAD Livestock Systems Research Unit, 7 ch. de I'IRAT, 97410, St Pierre, La Réunion

\section{Introduction}

Livestock production contributes significantly to global warming (Steinfeld et al., 2006), society and policy makers need information to better evaluate whether choosing more environment-friendly livestock products in human diets can mitigate global warning. Livestock products LCA studies available in the literature lack comparability because available assessments are conducted on different territories or with different methods (de Vries and de Boer, 2010).

\section{Method}

Taking the study case of the tropical island of La Réunion, 165 livestock farms were studied including major animal production: dairy milk, beef, pork, chicken, and rabbit. La Réunion farming systems are high input systems comparable to European ones. Based on the PLANETE tool (Risoud, 2002), a partial "cradle to farm-gate" LCA was conducted. Farm data on input consumption (including fertilisers \& fossil fuels) and output production (eg meat, manure) were collected from the records of the 165 farms. The inventory of direct greenhouse gas (GHG) emissions, mainly $\mathrm{CH}_{4}$ from enteric fermentation, and $\mathrm{CH}_{4}$ and $\mathrm{N}_{2} \mathrm{O}$ from excreta stored or laid out on pastures were based on the IPCC methodology. The inventory of indirect energy consumptions and $\mathrm{GHG}$ emissions (mainly $\mathrm{CO}_{2}$ ) were based on specific consumption data from La Réunion for water, fuel, electricity and gas. For industrial processes, European life cycle inventories were re-used (mostly from the Ecolnvent database) and extra energy costs and $\mathrm{CO}_{2}$ emissions were added to take into account the energy consumed for transport from Europe. As the primary function of livestock products is to satisfy the human body's need for nutrition two indicators were calculated: i) the quantity of crude energy produced per kg of fossil energy consumed (= energy use efficiency) and the quantity of GHG emitted per kg of protein produced. These indicators are useful in comparing products with variable water content such as milk and meat.

\section{Results}

This study yielded a consistent series of results for energy use efficiencies and GHG emissions between products (see Table 1). Production of $1 \mathrm{~kg}$ of beef protein has the highest impact on climate change, followed by milk and rabbit, whereas chicken and pork protein have the lowest impacts. Whatever the production, the rationing is the main source of fossil energy consumption ( $>30 \%)$. System performances for pork and chicken are more homogeneous because of their standardisation (see coefficients of variation). Differences in environmental impact can be explained mainly by three factors: difference in feed conversion efficiency, difference in reproduction and mortality rates and difference in enteric $\mathrm{CH}_{4}$ emissions.

Table 1 Technico-environmental performances for different livestock productions in La Réunion (2007)

\begin{tabular}{lcccccc}
\hline \hline & $\begin{array}{c}\text { Feed conversion } \\
\text { efficiency (kg } \\
\text { concentrate/kg product) }\end{array}$ & $\begin{array}{c}\text { Energy use efficiency } \\
\text { (kg crude energy/kg } \\
\text { fossil energy) }\end{array}$ & $\begin{array}{c}\text { Part of fossil energy } \\
\text { consumptions linked to } \\
\text { animal rationing (\%) }\end{array}$ & $\begin{array}{c}\text { GHG emissions } \\
\text { (kg CO } \mathrm{CO}_{2} \text {-eq./kg } \\
\text { protein) }\end{array}$ & $\begin{array}{c}\text { Coefficient } \\
\text { of variation } \\
(\%)\end{array}$ & $\begin{array}{c}\text { Part of enteric } \\
\mathrm{CH}_{4} \text { in total } \mathrm{GHG} \\
\text { emissions (\%) }\end{array}$ \\
\hline Milk (dairy) & 0.79 & 0.37 & 55.3 & 87.3 & 24.5 & 26.2 \\
Beef (suckling) & 4.00 & 0.19 & 31.9 & 239.7 & 66.5 & 65.5 \\
Beef (fattening) & 5.48 & 0.42 & 53.3 & 104.7 & 27.3 & 40.1 \\
Pork & 3.23 & 0.62 & 77.0 & 35.9 & 18.7 & 6.1 \\
Chicken & 2.19 & 0.36 & 75.3 & 25.9 & 15.6 & 1.8 \\
Rabbit & 3.99 & 0.15 & 58.8 & 83.2 & 28.8 & 2.3 \\
\hline \hline
\end{tabular}

\footnotetext{
†E-mail: jonathan.vayssieres@cirad.fr
} 


\title{
Discussion
}

Milk appears to be an environment-friendly product. Such differences between milk and meat products would certainly increase with the inclusion of post-farm-gate stages in the boundaries of the studied system because additional environmental impact during these stages is usually smaller for milk than for meat products. Based on our results, we could promote the substitution of red meat by white meat but conclusions have to be balanced. Compared with rations of ruminants, the rations of monogastric animals contain relatively more products, such as cereals, that humans could consume directly and more efficiently. Environmental consequences of this competition between humans and animals are not incorporated in this LCA study. Other aspects not considered that may affect conclusions of the study are $\mathrm{CO}_{2}$ emissions associated with land use change (e.g. deforestation for cultivation of feed crops) and the on-farm carbon storage on grasslands (greater for beef production). Moreover the production of food is the only function of livestock systems considered here and a consumer's choice among different types of livestock protein should not depend only on energy conversion and climate change. Other ecological functions, such as the production of fertilisers, the use of by-products and marginal lands, and landscape maintenance should also be integrated in a further, more holistic analysis.

\section{Conclusions}

In the perspective of mitigating global warming, results indicate that red meat may be substituted by milk and white meat products in the human diet. However, results need to be balanced because the LCA method applied does not consider determining elements such as consequences of land use change and competition for food crops between humans and animals. A more comprehensive view of the situation including other ecological functions of livestock activities is needed.

\section{References}

Steinfeld H, Gerber P, Wassenaar T, Castel V, Rosales M and de Haan C 2006. FAO, $319 \mathrm{p}$.

de Vries $M$ and de Boer IJM 2010. Livestock Science 128, 1-11.

Risoud B 2002. SOLAGRO - ENESAD - ADEME, 43 p.

doi:10.1017/S2040470010001238

\section{A participatory approach in agricultural development: A case study of a Research-Education-Development project to optimise mixed farming systems in Guadeloupe (FWI)}

\author{
Stark Fabien ${ }^{1 \dagger}$, Alexandre Régis ${ }^{2}$, Diman Christiane ${ }^{1}$, Alexandre Gisèle ${ }^{3}$, Diman Jean Louis ${ }^{4}$ \\ and Archimede Harry ${ }^{3}$
}

${ }^{1}$ EPLEFPA de la Guadeloupe; ${ }^{2}$ Chambre d'Agriculture de la Guadeloupe; ${ }^{3}$ INRA, UR143, 97170 Petit Bourg (FWI); ${ }^{4}$ INRA, UR1321, 97170 Petit Bourg (FWI)

\begin{abstract}
Introduction
This paper presents the methodology of a participatory Research - Education - Development (RED) project which is on-going in Guadeloupe studying mixed farming systems (MFS) (Stark et al., 2010). This project involves numerous local partners, ranging from researcher to farmers through to agricultural technical advisors. In our regional context, we aim to develop alternatives to specialised and intensified agricultural standards toward more sustainable farming systems. To do so, we based our approach on the assumption that the sustainability of a given farm would result (at least partly) from diversifying production and optimising complementarities and interactions between animal and crop productions (also termed integration), with attempts to keep productivity high. This needs a bottom-up approach through systemic methodology (Thornton and Herrero, 2001). This project would therefore lead to the design of innovative farming systems that would be evaluated on agro-ecological and socio-economical indicators (i.e., multicriteria evaluation) and thus create guidelines for farmers.
\end{abstract}

\section{Methodology}

Although $80 \%$ of Guadeloupe farms are MFS, limited information is available becuase there are many less studies covering systemic approaches than with sectorial approaches. In this context, our project has three steps.

Firstly, a descriptive analysis will be carried out to characterise MFS in Guadeloupe as well as identify different systems of production and of crop-animal integration that are currently present. Different methodologies would be used to describe and better understand MFS typology (Figure 1): (1) an exploratory study to identify MFS types, (2) a focus study to analyse and describe each identified system, and (3) an expert

\footnotetext{
† E-mail: Fabien.Stark@antilles.inra.fr
} 